\title{
Minilaparoscopic-assisted transvaginal approach in benign liver lesions
}

\author{
R. Castro-Pérez, E. Dopico-Reyes and L. R. Acosta-González \\ Department of General Surgery. University Hospital “Abel Santamaría Cuadrado”. University of Medical Sciences. \\ Pinar del Río. Cuba
}

\begin{abstract}
Objective: to report two benign liver lesions treatment under minilaparoscopic-assisted transvaginal approach.

Patients and methods: females, 44 and 45 years old, respectively, were treated. Patient 1 showed a $1,2 \mathrm{~cm} \varnothing$ tumor located in the left liver lobe. In preoperative studies was not possible to discern the etiology, for what was decided surgical treatment. The patient 2 showed a symptomatic liver simple cyst, $8 \mathrm{~cm} \varnothing$, located in the subsegment VI. She refused percutaneous treatment, it was recommended surgical treatment under general anesthesia. The surgical intervention offered was either the laparoscopic or the transvaginal approach, but this latter was accepted. Pneumoperitoneum with $15 \mathrm{mmHg}$ was used. Two small trocars were inserted into the abdomen. The first one $(5 \mathrm{~mm} \varnothing)$ at the umbilical region, the second one $(3 \mathrm{~mm} \varnothing)$ near the lesion. One trocar $11 \mathrm{~mm} \varnothing$, was placed in the posterior cul-de-sac. In patient 1 a large dissector was introduced adjacent to the trocar. In the patient 2 , one second trocar $5 \mathrm{~mm} \varnothing$ was introduced in vagina for operative instruments. Both specimens were extracted through the vagina, protected in extractor bags. Variables studied: operating room time; analgesia required and post-operative complications.
\end{abstract}

Results: the operating room times were 51 and $73 \mathrm{~min}$, respectively. Only the patient with hepatic liver cyst required postoperative analgesia for pain at the right upper quadrant. Both patients were discharged before 24 hours. No postsurgical complications were found in the 6 months follow up.

Conclusions: using transvaginal approach assisted with minilaparoscopy was possible to carry out surgical treatment in benign and non complex liver lesions located in outlying subsegments. It is a safe method with better aesthetic result than laparoscopic surgery. Nevertheless, will be necessary future studies that demonstrate the advantages of this approach in the hepatic lesions.

Key words: Transvaginal approach. NOTES. Minilaparoscopy. Liver resection. Liver tumor. Liver cyst. Inflammatory pseudotumor.

Received: 19-10-09.

Accepted: 22-10-09.

Correspondence: Raúl Castro Pérez. Servicio de Cirugía General. Hospital Provincial Docente “Abel Santamaría Cuadrado". Km. 89 Carretera Central. Ciudad de Pinar del Río. Provincia de Pinar del Río, Cuba. e-mail: castro@princesa.pri.sld.cu

\section{RESUMEN}

Objetivo: reportar dos casos de lesiones benignas del hígado tratadas quirúrgicamente mediante el abordaje transvaginal asistido por minilaparoscopia.

Pacientes y métodos: mujeres de 44 y 45 años de edad, respectivamente. La paciente 1 presentaba un pequeño tumor de $1,2 \mathrm{~cm}$ de $\varnothing$, en el lóbulo izquierdo del hígado. En su preoperatorio no se logró precisar su etiología y se decidió extirparlo quirúrgicamente. La paciente 2 presentaba un quiste simple del hígado muy sintomático de $8 \mathrm{~cm}$ de $\varnothing$ situado en el subsegmento VI, se negó a realizarse el tratamiento esclerosante por vía percutánea, por lo que se recomendó el tratamiento quirúrgico. Se les ofreció a ambas realizar la intervención mediante cirugía laparoscópica o el abordaje transvaginal, aceptando este último. El neumoperitoneo se realizó con presión de 15 $\mathrm{mmHg}$. Se colocaron 2 minipuertos en abdomen, uno en región umbilical de $5 \mathrm{~mm} \varnothing$ y el otro de $3 \mathrm{~mm} \varnothing$ en el sitio más próximo a la lesión. Con visión directa se colocó 1 trocar en la pared posterior del fondo del saco vaginal de $11 \mathrm{~mm} \varnothing$ para el paso de un endoscopio rígido. En la paciente 1 se utilizó este mismo orificio para, adyacente al trocar, introducir un disector largo. En la paciente 2 se introdujo un segundo trocar de $5 \mathrm{~mm}$ $\varnothing$ para el paso de instrumentos de trabajo. Ambos especímenes fueron extraídos a través de la vagina en bolsas extractoras. Se registró el tiempo quirúrgico, necesidad de analgésicos y complicaciones postoperatorias.

Resultados: los tiempos quirúrgicos fueron de 51 y 73 minutos, respectivamente. La paciente operada del quiste hepático requirió administración de analgésico postoperatorio. El alta hospitalaria fue dada antes de las 24 horas de la intervención. No se han presentado complicaciones postoperatorias relacionadas con el proceder después de un seguimiento mínimo de 6 meses.

Conclusiones: con el empleo de instrumentos rígidos, fue posible realizar el tratamiento quirúrgico de dos lesiones benignas del hígado, de poca complejidad y situadas en subsegmentos periféricos, de forma segura y con un mejor resultado estético que en la cirugía laparoscópica. No obstante, serán necesarios estudios futuros que demuestren las ventajas de esta vía de abordaje en las lesiones hepáticas.

Palabras claves: Abordaje transvaginal. NOTES. Minilaparoscopia. Resección hepática. Tumor hepático. Quiste hepático. Pseudotumor inflamatorio. 
Castro-Pérez R, Dopico-Reyes E, Acosta-González LR. Minilaparoscopic-assisted transuaginal approach in benign liver lesions. Rev Esp Enferm Dig 2010; 102: 357-364.

\section{INTRODUCTION}

Since the early decades of the past century, the vagina has been utilized as a natural orifice to entry in the abdominal cavity to facilitate diagnostic endoscopy procedures (1).

The application of endoscopic surgical operation by transvaginal approach was first carried out by Tsin et al. $(2,3)$, naming operative culdolaparoscopy and then, changed a few year later to MANOS (minilaparoscopicassisted natural orifice surgery), a broaden terminology which may also be applied to the other natural orifices (4).

In March of 2007, flexible endoscopes were incorporated into this type of surgery when Zorrón et al. (5) used this approach in Brazil to execute first transvaginal cholecystectomy (NOTES) in humans. In December of the same year, also using flexible instruments and assisted by minilaparoscopy, Noguera et al. (6) reported being successfully carried out the resection of a small benign liver tumor, demonstrating the possibility of performing operations in the upper abdomen, even more complex than cholecystectomy with a high level of safety and with minimal invasivity.

Endoscopic surgery by transvaginal approach was first carried out in Cuba a the $11^{\text {th }}$ of March, 2008 applied to a series of cholecystectomies performed in the Universitary Hospital Abel Santamaria Cuadrado located in the province of Pinar del Río (7).

The objectives of our report is to present the cases of two patients suffering for benign liver lesions operated by means of minilaparoscpic-assisted transvaginal approach using rigid instruments.

\section{PATIENTS AND METHODS}

\section{Patient 1}

Forty-four years old female with past history of good health, presented a clinical picture of low intensity epigastric pain which lasted 18 days of duration without associated symptoms. The family doctor prescribe an abdominal ultrasound (Fig. 1A) which revealed the entire of well defined hypoechoic tumor, which slightly elevated the Glisson's capsule, with a antero-posterior diameter of $1,2 \mathrm{~cm}$ situated in anterior face of the left hepatic lobe (Couinaud's hepatic segmentation). The hematological test result entire normal with the exception of erythrosed- imentation into which was somewhat accelerated with a value of $45 \mathrm{~mm} / \mathrm{L}$. The hepatic function test as well as the upper gastrointestinal tract and colon endoscopies showed no pathologies. The helicoidal computarized axial tomography results were dubious towards the etiology of the lesion. A cytological study was carried out aid on a biopsy taken using a fine needle, informed the presence of a chronic inflammatory lesion, ruling out the possibility of malignancy. The pathologist advice takes a large sample for a more precise diagnosis of the cause.

Because it's small size and superficial locations it was decided the total extirpation while revising the rest of the liver and abdomen cavity.

It was proposed to the patient to carry out the procedure by conventional laparoscopic surgery or by minilaparoscopic-assisted transvaginal approach. The details of both procedures were fully explained and the patient chose undergo the later.

Under authorization from the hospital ethics committee and the patient's informed consent the procedure was performed on the $19^{\text {th }}$ of March, 2009.

A single yellow color tumor was found situated near the hepatic union of the II and III subsegments, significantly elevating the Glisson's capsule (Fig. 1B), which was totally enucleated (Fig. 1 C-I).

The final histology results revealed an inflammatory pseudotumor of the liver, xanthogranuloma variety.

\section{Patient 2}

Forty-five year old female, presented with discomfort and pain in the right lumbar region which she had been suffering from for 2 months. She refers that in recent weeks the pain has prevented her to carry out her daily activities. An abdominal ultrasound revealed a simple hepatic cyst of about $8 \mathrm{~cm}$ in diameter located in the subsegment VI of the liver, which was later confirmed by CT-scan (Fig. 2A). There was no family history of polycystic disease. The patient rejected percutaneous treatment, so it was suggested to the patient that the intervention could be done by conventional laparoscopic surgery or by minilaparoscopicassisted surgery by transvaginal approach. Risks and benefits of both procedures were fully explained to the patient and she elected the later. Again under authorization of the hospital's Ethics Committee and the patient's informed consent, the procedure was performed on the $21^{\text {st }}$ of May, 2009 by means of unroofing the cyst (Fig. 2 B-I).

The pathology report confirmed the diagnosis of a simple hepatic cyst.

\section{Surgical procedures}

In both patients the procedure was conducted under endotracheal general anesthesia, $2 \mathrm{~g}$ of intravenous cefazolin were in concurrence with the department's protocol as a 


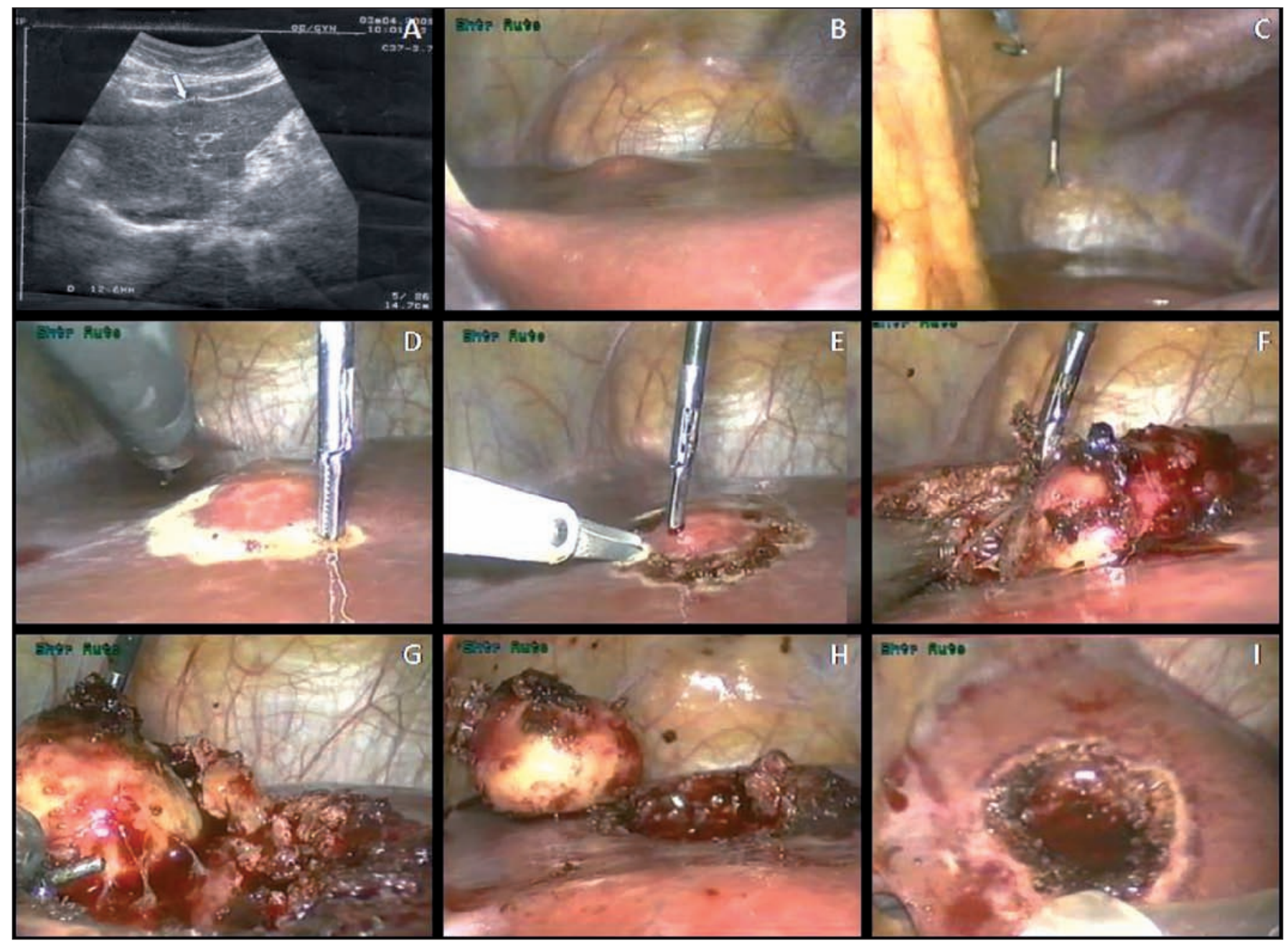

Fig. 1. A. Hypoechoic liver lesion (arrow). B. Protrusion in Glisson's capsule. C-I. Enucleation of the lesion.

standard dosage of prophylactic antibiotics. A modified lythotomy position was placed, as well as antisepsis measures of the abdomen wall, vagina, perineal region and the proximal third of the thighs were performed with iodopovidona $10 \%$, urine was removed with urinary catheter. A neumoperitoneum was created using a Veres needle at $15 \mathrm{mmHg}$ of pressure. A $5 \mathrm{~mm}$ trocar was introduced in the internal inferior border of the navel, through which a $5 \mathrm{~mm}$ $\varnothing 45^{\circ}$ laparoscope (Olympus) was introduced.

Under laparoscopic monitoring an $11 \mathrm{~mm} \varnothing$ trocar (Karl Storz) was introduced through the vaginal cul-desac into the peritoneal cavity, through which the extraction bag was introduced and later a $10 \mathrm{~mm} \emptyset, 43 \mathrm{~cm}$ long and $30^{\circ}$ telescope (Karl Storz 26003 BEA) (Figs. 3A and 3B). In patient 1 , was using same orifice for introduced adjacent $11 \mathrm{~mm}$ trocar, a $5 \mathrm{~mm} \varnothing 43 \mathrm{~cm}$ long dissector (Karl Storz $33427 \mathrm{MN}$ ). In patient 2, a second trocar (5 $\mathrm{mm} \emptyset$ ) was introduced parallel to the first for easier and usage of different additional instruments (Fig. 3C).

In both patients a $3 \mathrm{~mm} \varnothing$ minitrocar was introduced through the abdominal wall in the closest possible site to the lesion: epigastrium in patient 1 and for the right hypocondryum in patient 2 (Figs. 1C and 2D).

In the patient with the hepatic cyst a straight-needle suture was also introduce into the abdomen percutaneously to pierce the cyst wall and exteriorize it by the nearest entry, towards the traction function (Figs. 2C and 2D).

In both patients the specimens were extracted in extraction bag through the vagina (Fig. 3D).

The incision of the posterior cul-de-sac was closed using chromated catgut sutures.

Fentanil, a short-term analgesic was used during the procedure. The operation times, analgesics require and postoperatory complications were all considered and evaluated.

\section{RESULTS}

Surgery was performed on the two patients diagnosed with benign liver lesions. The first patient had a diagnosis of an inflammatory pseudotumor, the second with a very 


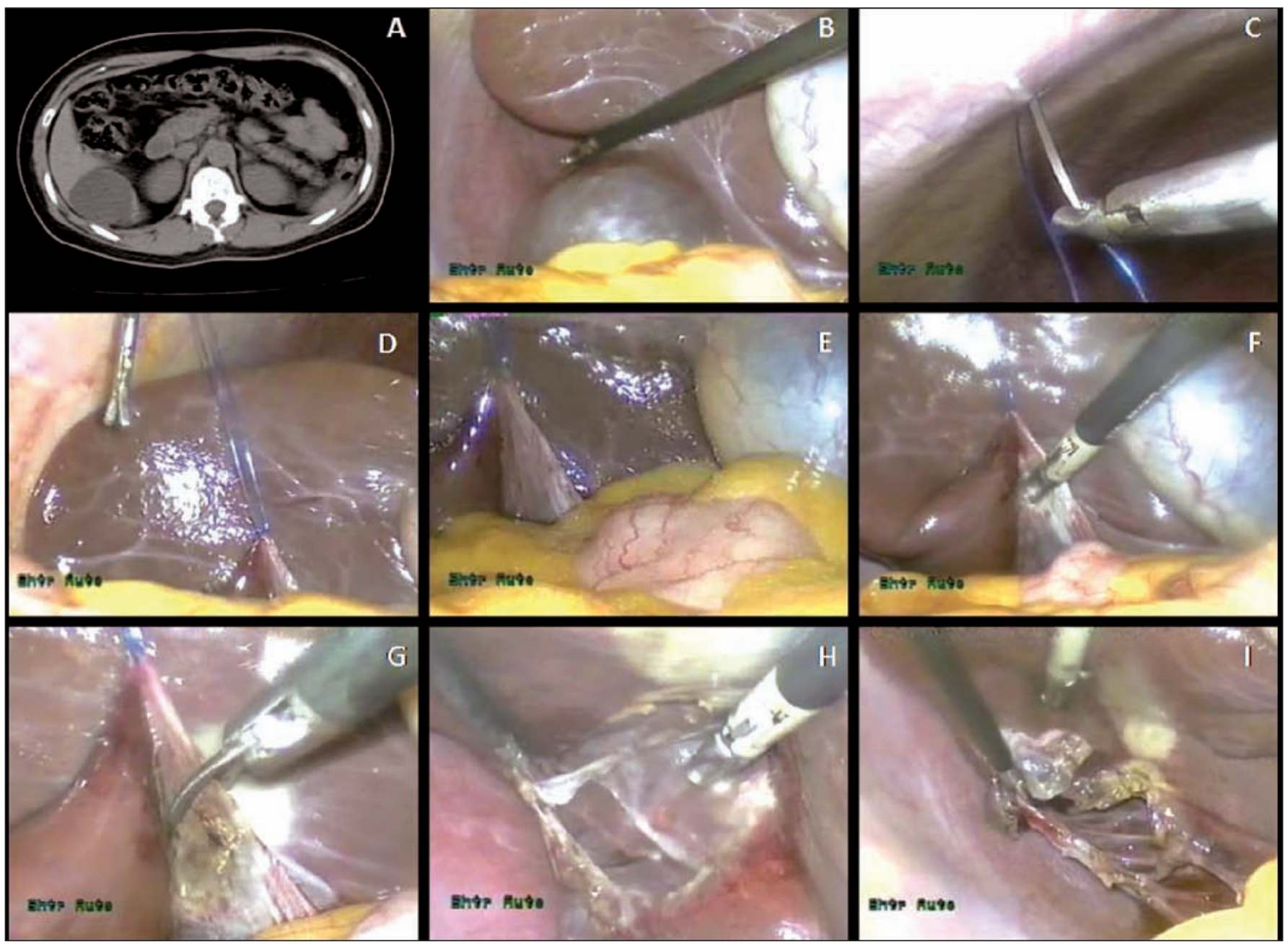

Fig. 2. A. CT-scan of the liver cyst. B. Liver cyst. C-E. Sraight-needle suture introduced into the abdomen percutaneously. F-I. Unroofing the cyst.

symptomatic simple cyst. The operating room times were 51 and 73 min respectively.

In recovery on the anesthesia ward only the patient operated for the simple cyst required analgesic, a single intramuscular dose of dipirona $600 \mathrm{mg}$ due to complaints of pain in the right hypochondrium.

By the next morning neither patient complaints of pain. An abdominal ultrasound was performed on both patient and no presence of fluid in the peritoneal cavity was detected. Both patients were discharged from the hospital just before completing 24 hours after their respective operations. A summary of each procedure was given to each patient to be submitted to their respective family physicians. Both were evaluated by the surgical staff weakly for the first month following their operation and once every trimester afterwards. Six months after their procedures neither present any complications or recidive of the lesions.

\section{DISCUSSION}

The advent of laparoscopic surgery demonstrated that the size of the incision had implications in the evolution and postoperative of the patients $(8,9)$ however; the application of minimally invasive techniques in the hepatic surgery, which were traditionally characterized by its larger incisions $(10,11)$, have had a very slow development. This can be attributed to multiple factors (12): the complexity of surgery on this particular organ, the possibility of causing an embolism of insufflated gas and the lack of laparoscopic surgical training in surgeons who have dedicated themselves to this field.

The first laparoscopic removal of hepatic tissue was performed by Gager et al. (13) in 1992; since which, numerous articles have been published concerning procedures which applied minimum access techniques in benign and malignant pathologies of the organ (13-22). 


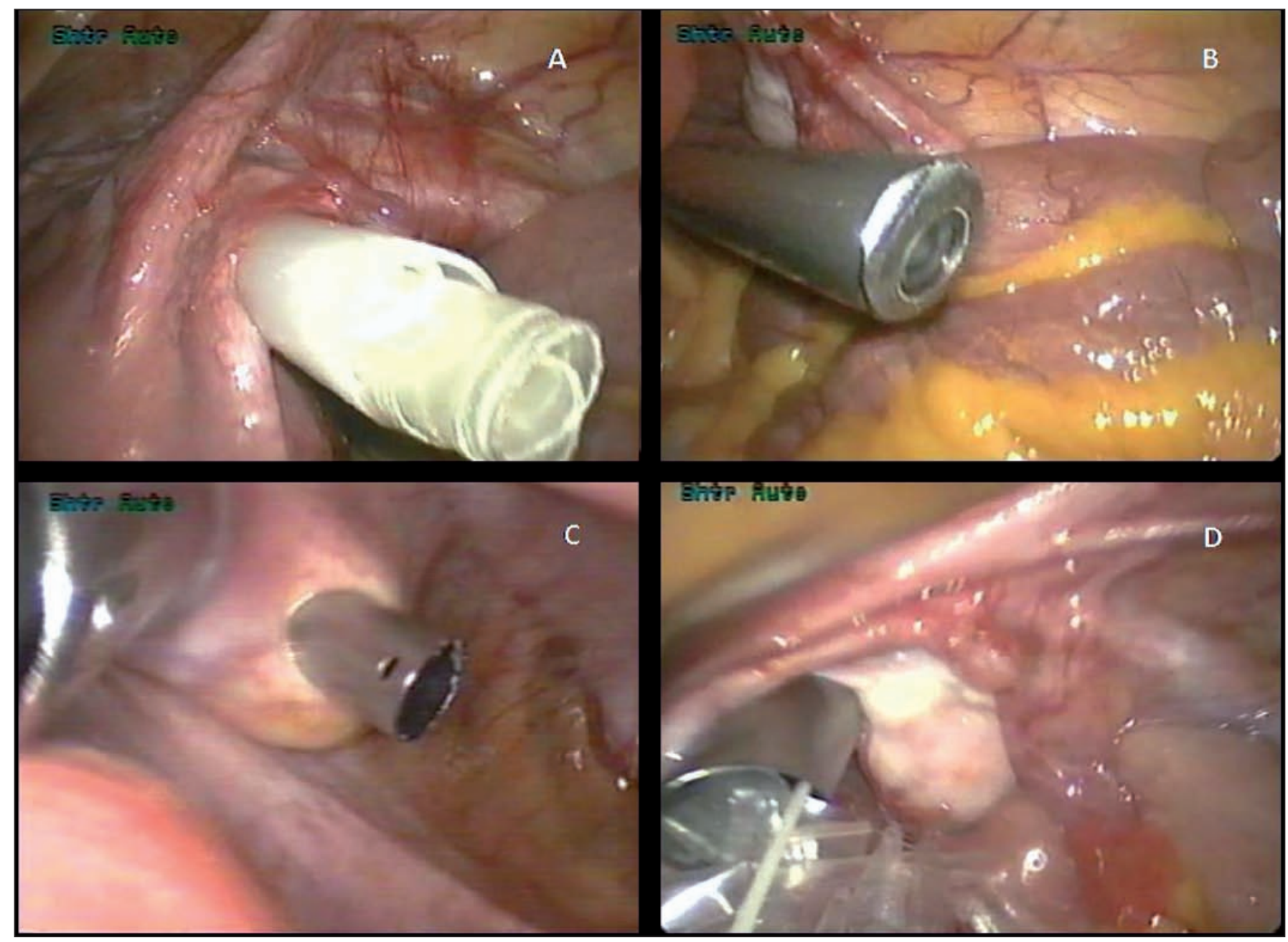

Fig. 3. A. Introduction of extraction bag. B. Introduction of endoscope. C. Transvaginal trocars (11 and $5 \mathrm{~mm} \varnothing)$ in cul-de-sac. D. Specimen extraction.

However, the majority of the procedures have been limited to lesions located in peripheral segments, major hepatic resections being less frequent. Despite recent proposals of new surgical techniques which seemingly simplify some of the removal procedures (23-26), and the optimistic articles recently published $(27,28)$, hepatic resections by laparoscopic surgery have yet to become fully standardized.

Surgery through natural orifices is currently under investigation, there are multiple clinical and technological barriers which impede further progress (29). Furthermore, there is no ideal natural orifice for carrying out surgical interventions within the abdominal cavity; each presents advantages and disadvantages with respect to the others (30). Transvaginal and transgatric approach has been the most studied in animal and human (31).

The peroral transgastric method has proven advantageous in the draining of pseudocysts, abscesses and pancreatic necrosectomies (9), this method has also been applied to surgical interventions in the abdominal cavity.
But the experience reached in last years with recent endoscopes, show that even it is necessary the aid at least of one miniport located in abdominal wall to carry out in a minor time and security (32). This could be one of the most promising methods in the future; however, its success depends on additional factors including: the control of contamination and the creation of flexible endoscopes or multi-channel transporters that facilitate safe entry into the peritoneal cavity, such equipment would enable the execution of efficient surgical interventions and guarantee a hermetic seal $(31,33,34)$. The application of the robotic technology and computer science could be important elements to be achieved $(35,36)$.

Actually, only the vagina has proved to be the most adequate natural orifice for surgical interventions in the peritoneal cavity (37). This route has a less dependence of the technology. Its closure is performed manually, which has proven to be simple, safe, and with minimal complications $(4,38)$. The elasticity of the vaginal walls also presents an additional advantage in that it allows for 
remove of larger specimens than those extracted in traditional laparoscopic surgery (39), its greatest disadvantage is that only half of the population could potentially benefit from this method.

In 2002, it was reported in medical literature (40) that it was possible to explore the abdomen and detect incidental lesions of the liver through the vagina. However, it was not until the 2007 that the first removal of a hepatic tumor by means of the vagina was performed by Noguera et al. (6) in Palma de Mallorca, Spain. Noguera and his team used a hybrid technique, introducing a flexible endoscope into the vagina with the assistance of two mini ports located in the abdominal wall: an umbilical port $5 \mathrm{~mm} \varnothing$ and a mini port measuring $3 \mathrm{~mm} \varnothing$ near to the lesion (right hypochondrium) to facilitate the dissection maneuvers.

We situated the same amount of ports in our two patients as the medical team did in Palma de Mallorca. The difference was that through the vagina we used a rigid telescope and an additional port for the passing of the $5 \mathrm{~mm} \varnothing$ work instruments.

In patient 1 , the lesion was situated at a greater distance from the vaginal (anterior face of the left lobe of the liver, near to the union of sub segments 2 and 3), in spite of that distance, it was still possible to adequately observe the entire procedure using a $30^{\circ}$ endoscope, although we believe that had a $45^{\circ}$ telescope been used it would have made the working conditions even more comfortable.

Due to the lesion's small size, its spherical form, its firm consistency and its superficial location elevating the Glisson's capsule, it was easily enucleated merely requiring monopolar electro coagulation. We decided enucleation without an oncological safety margin after being informed by the pathologist that the lesion was not malignant. The instruments utilized for the procedure were an electro coagulation hook, roticular scissors (introduced through the umbilical port), and a $43 \mathrm{~cm}$ long dissector (introduced through the vaginal port).

The pathology report indicated that there was an inflammatory pseudo tumor of the liver. These tumors actually fall under the category of myofibroblastic inflammatory tumors (41) which are very rare benign lesions of unknown etiology $(42,43)$ whose diameter may measure up to $25 \mathrm{~cm}$ (42). The majority of the reported cases had been diagnosed after surgical intervention (44) which also happened in our case. This can be attributed to the factors which complicate diagnosis (41); its clinical and radiological manifestations can simulate primitive malignant tumor, metastatic tumors, or hepatic abscesses. Furthermore, sometime the condition is seldom considered because its incidence is so rare.

The fine needle cytological biopsy has proven to be an ineffective means of achieving a precise diagnosis in these tumors $(41,45)$ which was the case in our patient; however, it generally enables us to differentiate them from malignant processes (46) which we were able to prove.
Seki et al. (47) published the first and only know case of a resection, by means of traditional laparoscopic surgery, of a small tumor $(10 \mathrm{~mm}$ diameter similar to our patients $12 \mathrm{~mm}$ tumor) which had been mistaken for a hepatic carcinoma. After the resection the specimen was extracted by amplifying the entry incision of one of the trocars located in the abdominal wall. In our case the pseudo tumor was extracted by way of the vagina, and the ports of the abdominal walls were of smaller diameter.

In recent years there has been an increase in the reports of pseudo inflammatory tumors of the liver with spontaneous regression (48) as well as the recommendations for conservative treatments (49) with antibiotics, anti-inflammatory non steroid drugs and steroid), both of which being dependant on the ability to employ the correct diagnostic procedures beforehand.

In patient 2 , the hepatic cyst was located in a region not easily accessed -the posterior external face of the right lobe of the liver (subsegment VI)-, which necessitated the retraction of the organ in order to expose the entire surface of the cyst, this was achieved using a suture thread introduced into the abdomen through the percutaneous route, by penetrating the cystic wall and exiting in close proximity to the point of entry we were able to exercise traction against it, achieving a rein function. Once the procedure was underway it became necessary to substitute the $3 \mathrm{~mm}$ mini port (located on the right hypochondrium) for a $3.9 \mathrm{~mm}$ port to allow for the insertion of forceps with a sturdier grip, because $3 \mathrm{~mm}$ port would not enable us to fulfill this objective. Following this slight modification was able to displace the inferior, external face of the right lobe of the liver and unroofing the cyst without difficulty. The $5 \mathrm{~mm}$ instruments which were used for the procedure (the bipolar electro coagulation forceps, grasping forceps and scissors) were introduced via the umbilical port as well as via the accessory vaginal port depending on which afforded the best anatomical position or angle to accomplish the resection.

Despite the fact that our proposal is based on a limited casuistry (only 2 patients) which will need to be substantiated with further studies, we believe that lesions located on the anterior sub segments and the more peripheral sub segments of the liver (III, IVB, V, VI) can de effectively treated using the transvaginal approach assisted by mini laparoscopy and performed by surgeons with previous experience in hepatic and minimum access surgeries using rigid endoscopes.

Rigid endoscopes offer various advantages including the following: they are more maneuverable; easily positioned in the surgical area and their lens systems facilitate excellent visualization and luminosity. However, the lesions located in the sub-segments near to the diaphragmatic dome (II, IVA, VII, and VIII) present a greater degree of difficulty on account of convexity of the organ which acts as a natural barrier and impedes sufficient access to the lesions located there. It would be equally difficult to attempt an approach of any organ located in a non 
frontal position in relation to the abdominal orifice entrance, thus it is evident that in such instances flexible endoscopes would be more appropriate despite their limitations.

The transvaginal approach permits the usage of both rigid and flexible instruments, however, we are of the opinion that although the latter mentioned have yet to be perfected they can be effective, and we must weigh the pros and the cons that each would present when deciding which to use in a specific patient.

Transvaginal surgery assisted by mini laparoscopy can be converted into laparoscopic surgery in unforeseen circumstances by simply increasing the quantity and diameter of the ports in the abdominal wall. It can also be converted into open surgery if made necessary. It should be performed by surgeons with experience in laparoscopic and hepatic surgery.

Using the transvaginal approach assisted by mini laparoscopy, with the usage of rigid instruments it is possible to safely perform surgical treatments of simple, benign liver lesions located in peripheral segments of the liver, with better aesthetic results that can be achieved by traditional laparoscopic surgery.

\section{REFERENCES}

1. Christian J, Barrier BF, Schust D, Miedema B, Thaler K. Culdoscopy: a foundation for natural orifice surgery -past, present, and future. J Am Coll Surg 2008; 207(3): 417-22.

2. Tsin DA, Liliana T, Colombero LT, Mahmood D, Padouvas J, Manolas P. Operative culdolaparoscopy: a new approach combining operative culdoscopy and minilaparoscopy. J Am Assoc Gynecol Laparosc 2001; 8(3): 438-41.

3. Tsin DA, Sequeira RJ, Giannikas G. Culdolaparoscopic cholecystectomy during vaginal hysterectomy. JSLS 2003; 7: 171-2.

4. Tsin DA, Colombero LT, Lambeck J, Manolas P. Minilaparoscopyassisted natural orifice surgery. JSLS 2007; 11: 24-9.

5. Zorrón R, Filgueiras M, Maggioni LC, Pombo L, Lopes G, Lacerda A. NOTES transvaginal cholecystectomy: report of the first case. Surgical Innovation 2007; 14(4): 278-83

6. Noguera JF, Dolz C, Cuadrado A, Olea JM, Vilella A. Transvaginal liver resection (NOTES) combined with minilaparoscopy. Rev Esp Enferm Dig 2008; 100: 411-5.

7. Castro R, Acosta LR, Dopico E, Robaina LE. MANOS: colecistectomías transvaginales. Reporte preliminar. Cir Esp 2009; 85(5): 292-7.

8. Cugat E, Varas MJ. Cirugía endoscópica por orificios naturales (NOTES). ¿Visión de futuro? Rev Esp Enferm Dig 2008; 100(7): 383-6.

9. Varas MJ, Espinós JC, Bardají M. Cirugía endoscópica transluminal por orificios naturales (NOTES). Rev Esp Enferm Dig 2009; 101(4): $275-82$.

10. Tung TT. Les resections majeures et mineures du foie. Paris: Masson; 1979.

11. Castro R, Mijares E, Dopico E, Mustafá LR. Resecciones hepáticas regladas por la técnica de la digitoclasia. Experiencia en 11 años. Rev Cubana Cir 1996; 35(1). Disponible en: http://scielo.sld.cu/scielo. php?script $=$ sci_arttext $\&$ pid $=$ S0034-74931996000100009\& lng=es\&nrm=iso\&tlng=es

12. Cugat E, García MI, Bretcha P, Rodríguez A, Marco C. Laparoscopia y cirugía hepática: técnica e indicaciones. Cir Esp 2004; 75(1): 23-8.

13. Gagner M, Rheault M, Dubuc J. Laparoscopic partial hepatectomy for liver tumor. Surg Endosc 1992; 6: 99.

14. Azagra JS, Gowergen M, Gilbart E, Jacobs D. Laparoscopic anatom- ical left lateral segmentectomytechnical aspect. Surg Endosc 1996; 10: 758-61.

15. Cherqui D, Husson E, Hammoud R, Malassagne B, Stephan F, Bensaid S, et al. Laparoscopic liver resections: a feasibility study in 30 patients. Ann Surg 2000; 232: 753-62.

16. Farges O, Jagot P, Kirstetter P, Marty J, Belghiti J. Prospective assessment of the safety and benefit of laparoscopic liver resections. J Hepatobiliary Pancreat Surg 2002; 9: 242-8.

17. Gigot JF, Glineur D, Santiago Azagra J, Goergen M, Ceuterick M, Morino M, et al. Laparoscopic liver resection for malignant liver tumors: preliminary results of a multicenter European study. Ann Surg 2002; 236: 90-7.

18. Descottes B, Glineur D, Lachachi F, Valleix D, Paineau J, Hamy A, et al. Laparoscopic liver resection of benign liver tumors. Surg Endosc 2003; 17: 23-30.

19. Mala T, Edwin B, Rosseland AR, Gladhaug I, Fosse E, Mathisen O. Laparoscopic liver resection: experience of 53 procedures at a single center. J Hepatobiliary Pancreat Surg 2005; 12: 298-303.

20. Borzellino G, Ruzzenente A, Minicozzi AM, Giovinazzo F, Pedrazzani C, Guglielmi A. Laparoscopic hepatic resection. Surg Endosc 2006; 20: 787-90.

21. Vibert E, Perniceni T, Levard H, Denet C, Shahri NK, Gayet B. Laparoscopic liver resection. Br J Surg 2006; 93: 67-72.

22. Dagher I, Proske JM, Carloni A, Richa H, Tranchart H, Franco D. Laparoscopic liver resection: results for 70 patients. Surg Endosc 2007; 21: 619-24.

23. Machado MA, Makdissi FF, Bacchella T, Machado MC. Hemihepatic ischemia for laparoscopic liver resection. Surg Laparosc Endosc Percutan Tech 2005; 15(3): 180-3.

24. de Santibáñes E, Sánchez Clariá R, Palavecino M, Beskow A, Pekolj J. Liver metastasis resection: a simple technique that makes it easier. J Gastrointest Surg 2007; 11: 1183-7.

25. Hilal MA, Pearce NW. Laparoscopic left lateral liver sectionectomy: a safe, efficient, reproducible technique. Dig Surg 2008; 25: 305-8.

26. Makdissi FF, Surjan RC, Machado MA. Laparoscopic enucleation of liver tumors. Corkscrew technique revisited. J Surg Oncol 2009; 99: 166-8.

27. Koffron AJ, Auffenberg G, Kung R, Abecassis M. Evaluation of 300 minimally invasive liver resections at a single institution. Less is more. Ann Surg 2007; 246(3): 385-94.

28. Inagaki H, Kurokawa T, Yokoyama T, Ito N, Yokoyama Y, Nonami T. Results of laparoscopic liver resection: retrospective study of 68 patients. J Hepatobiliary Pancreat Surg 2009; 16: 64-8.

29. Rattner D, Kalloo A. ASGE/SAGES Working Group on Natural Orifice Transluminal Endoscopic Surgery. Surg Endosc 2006; 20: 32933.

30. Moran EA, Gostout CH. Anatomical Considerations for natural orifice translumenal endoscopic surgery. Clin Anat 2009; 22: 627-32.

31. Sodergren MH, Clark J, Athanasiou T, Teare J, Yang GZ, Darzi A. Natural orifice translumenal endoscopic surgery: critical appraisal of applications in clinical practice. Surg Endosc 2009; 23: 680-7.

32. Dallemagne B, Perretta S, Allemann P, Asakuma M, Marescaux J. Transgastric hybrid cholecystectomy. Br J Surg 2009; 96: 1162-6.

33. Sumiyama K, Gostout Ch, Gettman MT. Status of access and closure techniques for NOTES. J Endourol 2009; 23(5): 765-71.

34. Fritscher-Ravens A. A market for gastric NOTES closure: which path should we follow? Endoscopy (Editorial) 2009; 41: 160-161

35. Canes D, Amy C. Lehman AC, Farritor SH, Oleynikov D, Desai MM. The Future of NOTES Instrumentation: flexible robotics and in vivo minirobots. J Endourol 2009; 23(5): 787-92.

36. Marescaux J, Perretta S. NOTES: Un nuevo abordaje mínimamente invasivo. Cir Esp 2009; 85(5): 265-7.

37. Box GN, Bessler M, Clayman RV. Transvaginal access: current experience and potential implications for urologic applications. Journal of Endourology 2009; 23(5): 753-7.

38. Zornig C, Mofid H, Siemssen L, Emmermann A, Alm M, von Waldenfels HA, et al. Transvaginal NOTES hybrid cholecystectomy: feasibility results in 68 cases with mid-term follow-up. Endoscopy 2009; 41: 391-4

39. Gill IS, Cherullo EE, Meraney AM, Borsuk F, Murphy DP, Falcone $\mathrm{T}$. Vaginal extraction of the intact specimen following laparoscopic radical nephrectomy. J Urol 2002; 167: 238-41.

40. Tsin DA, Bumaschny E, Helman M, Colombero L. Culdola- 
paroscopy oophorectomy with vaginal hysterectomy an optional minimal-access surgical technique. J Laparoendosc Adv Surg Tech 2002; 12: 269-71.

41. Dergal E, Capurso M, Garmilla JG, Guzmán L, Navarro L, Hernández JA. Pseudotumor inflamatorio de focos múltiples en hígado. Informe de un paciente. Cir Gen 2002; 24: 47-52.

42. Li GH, Li JQ, Lin YZ. Inflammatory pseudotumor of the liver. J Surg Oncol 1989; 42: 244-8.

43. Nakanuma Y, Tsuneyama K, Masuda S, Tomioka T. Hepatic inflammatory pseudotumor associated with chronic cholangitis: report of three cases. Hum Pathol 1994; 25: 86-91.

44. Jackson RB, Gatling RR. Inflammatory pseudotumor of the liver. Surgery $1991 ; 109: 329-32$
45. Hosler GA, Steinberg DM, Sheth S, Hamper UM, Erozan YS, Ali SZ. Inflammatory pseudotumor: a diagnostic dilemma in cytopathology. Diagnostic Cytopathology 2004; 31(4): 267-70.

46. Zamir D, Jarchowsky J, Singer C, Abumoch S, Groisman G, Ammar $\mathrm{M}$, et al. Inflammatory pseudotumor of the liver-a rare entity and a diagnostic challenge. Am J Gastroenterol 1998; 93: 1538-40.

47. Seki S, Sakaguchi H, Oiso R, Lee C, Morikawa H, Hamba H, et al. Laparoscopic partial hepatectomy for inflammatory pseudotumor of the liver. Endoscopy 2001; 33: 294.

48. Yamaguchi J, Sakamoto Y, Sano T, Shimada K, Kosuge T. Spontaneous regression of inflammatory pseudotumor of the liver: report of three cases. Surg Today 2007; 37: 525-9.

49. Stringer MD. Liver tumors. Semin Pediatr Surg 2000; 9: 196-208. 